Article

\title{
Biotransformation of Lactones with Methylcyclohexane Ring and Their Biological Activity
}

\author{
Katarzyna Wińska ${ }^{1, *}$, Małgorzata Grabarczyk ${ }^{1}$, Wanda Mączka ${ }^{1}$, Barbara Żarowska ${ }^{2}$, \\ Gabriela Maciejewska ${ }^{3}$, Katarzyna Dancewicz ${ }^{4}$, Beata Gabryśs ${ }^{4}$ and Mirosław Anioł ${ }^{1}$ \\ 1 Department of Chemistry, Wroclaw University of Environmental and Life Sciences, Norwida 25, \\ Wrocław 50-375, Poland; magrab@onet.pl (M.G.); wanda_m19@o2.pl (W.M.); \\ miroslaw.aniol@up.wroc.pl (M.A.) \\ 2 Department of Biotechnology and Food Microbiology, Wroclaw University of Environmental and Life \\ Sciences, Chełmońskiego 37/41, Wrocław 51-630, Poland; barbara.zarowska@up.wroc.pl \\ 3 Faculty of Chemistry, Wrocław University of Technology, Wybrzeże Wyspiańskiego 27, Wrocław 50-370, \\ Poland; gabriela.maciejewska@pwr.edu.pl \\ 4 Department of Botany and Ecology, University of Zielona Gora, Szafrana 1, Zielona Gora 65-516, Poland; \\ k.dancewicz@wnb.uz.zgora.pl (K.D.); b.gabrys@wnb.uz.zgora.pl (B.G.) \\ * Correspondence: katarzyna.winska@up.wroc.pl; Tel.: +48-71-3205-213
}

Academic Editor: Miguel Yus Astiz

Received: 14 November 2016; Accepted: 19 December 2016; Published: 24 December 2016

\begin{abstract}
The aim of the study was to obtain biological active compounds during biotransformation. Three bicyclic halolactones with methylcyclohexane ring (2-chloro-4-methyl-9-oxabicyclononan-8-one, 2-bromo-4-methyl-9-oxabicyclo[4.3.0]nona- -8-one and 2-iodo-4-methyl-9oxabicyclo[4.3.0]nonan-8-one) obtained from the corresponding $\gamma, \delta$-unsaturated acid were subjected to a screening biotransformation using 22 fungal strains. Two of these strains (Cunninghamella japonica AM472 and Fusarium culmorum AM10) were able to transform halolactones into 2-hydroxy-4-methyl-9-oxabicyclo[4.3.0]nonan-8-one by hydrolytic dehalogenation with good yield. The biotransformation product was structurally different from its synthetically prepared analog. All halolactones and hydroxylactones were tested for their biological activity. The chlorolactone inhibited growth of Staphylococcus aureus ( $\max \Delta \mathrm{OD}=0)$, Escherichia coli $(\max \Delta \mathrm{OD}=0.3$ ) and Candida albicans ( $\max \triangle \mathrm{OD}=0$ ) strains. Bromolactone caused inhibition of growth of Staphylococcus aureus $(\max \Delta \mathrm{OD}=0)$ and Fusarium linii $(\max \Delta \mathrm{OD}=0)$ strains. Iodolactone limited growth of Staphylococcus aureus ( $\max \Delta \mathrm{OD}=0)$, Escherichia coli $(\max \Delta \mathrm{OD}=0.25)$, Candida albicans ( $\max \Delta \mathrm{OD}=0.45)$ and Pseudomonas fluorescens $(\max \Delta \mathrm{OD}=0.42)$ strains. Hydroxylactone caused inhibition of growth of Staphylococcus aureus (max $\Delta \mathrm{OD}=0.36$ ) and Pseudomonas fluorescens ( $\max \Delta \mathrm{OD}=0.39)$ strains only. The test performed on aphids Myzus persicae (Sulz.) showed that chloro- and bromolactone exhibited deterrent activity after $24 \mathrm{~h}$ (ID $=0.5$ and 0.4 , respectively), while hydroxylactone was a weak attractant $(I D=-0.3)$.
\end{abstract}

Keywords: lactones; hydrolytic dehalogenation; antimicrobial activity; deterrent activity

\section{Introduction}

The compounds containing the lactone moiety are one of the most interesting groups in terms of biological properties. They are found in every ecosystem because they are the products of the secondary metabolism of microorganisms [1], insects [2], plants [3] and even marine organisms [4]. Lactones have a wide spectrum of biological activity and are quite a large group of compounds with bactericidal $[5,6]$, fungicidal $[7,8]$ or cytotoxic activities $[9,10]$. Tetrenoline, a lactone with the polyene 
bond system, is primarily bactericidal, particularly against Gram-positive bacteria [11]. Acetomycin was isolated from Streptomyces ramulosus and inhibited the growth of colonies of protozoans [12-14]. Sesquiterpene lactones, costunolide and dehydrocostuslactone from Laurus spp. had anti-tuberculous activity against Mycobacterium tuberculosis [15]. One of the best known deterrents to storage pests were allantolactone, izoalantolactone and ent-izoalantolactone [16]. Studies carried out in our department confirmed the deterrent activity of bicyclic lactones against pests of grain storage [17]. The natural sesquiterpene lactone 8-deoxylactucune, which was isolated from Cichorium endivia, absorbed UVB radiation and partially protected the formation of pyrimidine dimers and IL-6 mRNA in the human keratinocyte cell line HaCaT [18]. Lactones isolated from Rolandra fruticosa were used to treat arthritis and diabetes [19]. Monoterpenoid lactone liguhodgcin was isolated from Ligularia hodgsonii and was used in traditional Chinese medicine in the treatment of flu, coughs, ulcers and tuberculosis. In addition, this compound proved to be moderately active against the cell lines HL-60 (leukemia), SMMC-7721 (hepatoma) and HeLa (cervical carcinoma) [20].

These interesting biological properties made them the subject of research. In order to recognize the properties of lactones, such compounds may be isolated from natural sources, chemically synthesized and also prepared by biotransformation. One of the most desirable processes is the obtaining of new lactones and their additional functionalization involving the regioselective hydroxylation. Our team is working on obtaining the lactones by biotransformation and their microbiological functionalization in order to develop compounds of higher biological activity [21,22]. In this paper, we present the results which we have received for the group of bicyclic lactones with a methyl group.

\section{Materials and Methods}

\subsection{General Information}

GC analysis was carried out on an Agilent Technologies 6890N instrument (Varian, Agilent Technologies, Santa Clara, CA, USA) using a DB-17 column (cross-linked methyl silicone gum, $30 \mathrm{~m} \times 0.32 \mathrm{~mm} \times 0.25 \mu \mathrm{m}),(\mathrm{J} \& \mathrm{~W}$ Scientific, Folsom, CA, USA), retention times were as follows: $3.7 \mathrm{~min}$ for chlorolactone (SI, Figure S1) $4.1 \mathrm{~min}$ for bromolactone (SI, Figure S2), $4.7 \mathrm{~min}$ for iodolactone (SI, Figure S3) and $4.0 \mathrm{~min}$ for hydroxylactone (SI, Figure S4). The enantiomeric excesses of the products obtained during biotransformation were determined by GC analysis using the chiral column Supelco $\beta$-DEX $325(30 \mathrm{~m} \times 0.25 \mathrm{~mm} \times 0.25 \mu \mathrm{m})$ (Supelco Bellefonte, PA, USA) under the following conditions: injector $200{ }^{\circ} \mathrm{C}$, detector (FID) $250{ }^{\circ} \mathrm{C}$, column temperature: $140{ }^{\circ} \mathrm{C}$ (hold $45 \mathrm{~min}$ ), $140-200{ }^{\circ} \mathrm{C}$ (rate $20^{\circ} \mathrm{C} / \mathrm{min}$ ), and $200^{\circ} \mathrm{C}$ (hold $1 \mathrm{~min}$ ), retention times of hydroxylactone were as follows: $\mathrm{R}_{\mathrm{t}}(+)-5$ : $12.78 \mathrm{~min}$ and $\mathrm{R}_{\mathrm{t}}(-)-5: 13.29 \mathrm{~min}, \mathrm{R}_{\mathrm{S}}=2.89$ (SI, Figures S5-S8). Enantiomeric excess was calculated:

$$
e e=\frac{E 1-E 2}{E 1+E 2} 100 \%
$$

E1-peak area of compound one; E2—peak area of compound two.

The molar masses of the new products were confirmed by high resolution mass spectrometry analysis using a Waters LCT Premier XE instrument (ESI ionisation) (Waters Division, Milford, MA, USA).

${ }^{1} \mathrm{H}$ NMR spectra were recorded in a $\mathrm{CDCl}_{3}$ solution on a Bruker Avance DRX $300 \mathrm{MHz}$ spectrometer (Bruker, Billerica, MA, USA) or on a Bruker Avance ${ }^{\mathrm{TM}} 600 \mathrm{MHz}$ spectrometer (Bruker, Billerica, MA, USA). IR spectra were recorded on a Thermo-Nicolet IR300 FT-IR spectrometer (Waltham, MA, USA). Optical rotations were determined on a P-2000 polarimeter (Jasco, Easton, PA, USA) in chloroform solutions. The melting points were determined on a Boetius apparatus. The refractive index was measured on Carl Zeiss Abbe and Pulfrich refractometer (Jena, Germany). 


\subsection{Synthesis of Substrates}

2-Chloro-4-methyl-9-oxabicyclo[4.3.0]nonan-8-one (2)

Chlorolactonization of acid 1 (1.71 g, $0.011 \mathrm{~mol})$, according to the known procedure [22] gave chlorolactone $2(1.23 \mathrm{~g}, 0.0065 \mathrm{~mol})$ in $59 \%$ yield. The physical and spectral data of this product are as follows: $\mathrm{n}_{\mathrm{D}}=1.4900,{ }^{1} \mathrm{H}$ NMR $\left(600 \mathrm{MHz}, \mathrm{CDCl}_{3}\right): 0.93\left(\mathrm{~d}, J=6.5 \mathrm{~Hz}, 3 \mathrm{H}, \mathrm{CH}_{3}-9\right), 1.61(\mathrm{ddd}$, $J=14.8,11.8$ and $\left.3.2 \mathrm{~Hz}, 2 \mathrm{H}, \mathrm{CH}_{2}-5\right), 1.71-1.79\left(\mathrm{~m}, 1 \mathrm{H}\right.$, one of $\left.\mathrm{CH}_{2}-3\right), 1.88-1.94\left(\mathrm{~m}, 1 \mathrm{H}\right.$, one of $\left.\mathrm{CH}_{2}-3\right)$, 1.98-2.04 (m, 1H, H-4), $2.23\left(\mathrm{~d}, J=16.4 \mathrm{~Hz}, 1 \mathrm{H}\right.$, one of $\left.\mathrm{CH}_{2}-7\right), 2.68(\mathrm{dd}, \mathrm{J}=16.4$ and $6.2 \mathrm{~Hz}, 1 \mathrm{H}$, one of $\left.\mathrm{CH}_{2}-7\right), 2.69-2.75(\mathrm{~m}, 1 \mathrm{H}, \mathrm{H}-6), 4.47-4.49$ (m, $\left.1 \mathrm{H}, \mathrm{H}-2\right), 4.55(\mathrm{dd}, J=5.5$ and $2.7 \mathrm{~Hz}, 1 \mathrm{H}, \mathrm{H}-1),{ }^{13} \mathrm{C} \mathrm{NMR}$ (151 MHz, CDCl $)$ ): 21.5 (C-9), 23.2 (C-4), 32.1 (C-6), 35.6 (C-3), 35.8 (C-5), 38.1 (C-7), 55.2 (C-1), 79.8 (C-2), 175.9 (C-8), IR (KBr, cm ${ }^{-1}$ ): 2954, 1787, 1457, 1161, 1019, 976, ESIHRMS: calcd for $\mathrm{C}_{9} \mathrm{H}_{13} \mathrm{ClO}_{2} \mathrm{Na}$, $m / z 211.0502(\mathrm{M}+\mathrm{H})^{+}$, found 211.0508. (SI, Figures S9-S14)

2-Bromo-4-methyl-9-oxabicyclo[4.3.0]nonan-8-one (3)

Bromolactonization of acid 1 (1.71 g, $0.011 \mathrm{~mol})$, according to the known method [23] gave bromolactone $3(2.1 \mathrm{~g}, 0.0090 \mathrm{~mol})$ in $82 \%$ yield. The physical and spectral data of this product are as follows: $\mathrm{n}_{\mathrm{D}}=1.5150,{ }^{1} \mathrm{H} \mathrm{NMR}\left(600 \mathrm{MHz}, \mathrm{CDCl}_{3}\right): 0.93\left(\mathrm{~d}, J=6.3 \mathrm{~Hz}, 3 \mathrm{H}, \mathrm{CH}_{3}-9\right), 1.66(\mathrm{ddd}$, $J=15.0,11.9$ and $\left.3.3 \mathrm{~Hz}, 2 \mathrm{H}, \mathrm{CH}_{2}-5\right), 1.69-1.79\left(\mathrm{~m}, 1 \mathrm{H}\right.$, one of $\left.\mathrm{CH}_{2}-3\right), 1.93-2.00\left(\mathrm{~m}, 1 \mathrm{H}\right.$, one of $\left.\mathrm{CH}_{2}-3\right)$, 2.01-2.03 (m, 1H, H-4), $2.23\left(\mathrm{~d}, J=16.4 \mathrm{~Hz}, 1 \mathrm{H}\right.$, one of $\left.\mathrm{CH}_{2}-7\right), 2.68(\mathrm{dd}, J=16.4$ and $6.3 \mathrm{~Hz}, 1 \mathrm{H}$, one of $\left.\mathrm{CH}_{2}-7\right), 2.74-2.84(\mathrm{~m}, 1 \mathrm{H}, \mathrm{H}-6), 4.58-4.60(\mathrm{~m}, 1 \mathrm{H}, \mathrm{H}-2), 4.65(\mathrm{dd}, J=5.3$ and $2.6 \mathrm{~Hz}, 1 \mathrm{H}, \mathrm{H}-1),{ }^{13} \mathrm{C}$ NMR (151 MHz, $\mathrm{CDCl}_{3}$ ): 21.4 (C-9), 24.3 (C-4), 32.1 (C-6), 35.7 (C-3), 36.0 (C-5), 38.4 (C-7), 47.6 (C-1), 80.1 (C-2), 176.1 (C-8), IR (KBr, cm $\left.{ }^{-1}\right)$ : 2957, 1799, 1457, 1158, 1016, 973, ESIHRMS: calcd for $\mathrm{C}_{9} \mathrm{H}_{13} \mathrm{BrO}_{2} \mathrm{Na}$, $m / z 254.9997$ and $256.9977(\mathrm{M}+\mathrm{H})+$, found 254.9986 and 256.9917. (SI, Figures S15-S20)

2-Iodo-4-methyl-9-oxabicyclo[4.3.0]nonan-8-one (4)

Iodolactonization of acid $\mathbf{1}(1.36 \mathrm{~g}, 0.0088 \mathrm{~mol})$ according to the known procedure [24] gave iodolactone $4(2.1 \mathrm{~g}, 0.0075 \mathrm{~mol})$ in $83 \%$ yield. The physical and spectral data of this product are as follows: ${ }^{1} \mathrm{H}$ NMR $\left(300 \mathrm{MHz}, \mathrm{CDCl}_{3}\right): 0.80-0.88\left(\mathrm{~m}, 1 \mathrm{H}\right.$ one of $\left.\mathrm{CH}_{2}-5\right), 0.94\left(\mathrm{~d}, J=6.5 \mathrm{~Hz}, 3 \mathrm{H}, \mathrm{CH}_{3}-9\right), 1.44-1.54(\mathrm{~m}$, $1 \mathrm{H}$ one of $\left.\mathrm{CH}_{2}-5\right), 1.69-1.74\left(\mathrm{~m}, 1 \mathrm{H}\right.$, one of $\left.\mathrm{CH}_{2}-3\right), 1.90\left(\mathrm{~d}, J=16.3 \mathrm{~Hz}, 1 \mathrm{H}\right.$, one of $\left.\mathrm{CH}_{2}-3\right), 1.98-2.00$ $(\mathrm{m}, 1 \mathrm{H}, \mathrm{H}-4), 2.21\left(\mathrm{~d}, J=16.7 \mathrm{~Hz}, 1 \mathrm{H}\right.$, one of $\left.\mathrm{CH}_{2}-7\right), 2.66\left(\mathrm{dd}, J=16.7\right.$ and $6.4 \mathrm{~Hz}, 1 \mathrm{H}$, one of $\left.\mathrm{CH}_{2}-7\right)$, 2.80-2.90 (m, 1H, H-6), 4.66 (m, 1H, H-2), 4.80 (m, 1H, H-1), IR (film, cm ${ }^{-1}$ ): 2972, 1792, 1164, 960.

\subsection{Microorganisms and Growing Conditions}

The fungal and yeast strains used for biotransformation came from the collection of the Department of Chemistry, Wroclaw University of Environmental and Life Sciences. There were: Fusarium culmorum AM10, Fusarium avenaceum AM11, Fusarium oxysporum AM13, Fusarium tricinctum AM16, Fusarium semitectum AM20, Fusarium oxysporum AM21, Fusarium equiseti AM22, Fusarium solani AM203, Penicillium vermiculatum AM30, Penicillium camembertii AM83, Penicillium chermesinum AM13, Penicillium frequentans AM351, Aspergillus wentii AM413, Aspergillus ochraceus AM456, Absidia corerulea AM93, Syncephalastrum racemosum AM105, Cunninghamella japonica AM472, Pleurotus ostreatus AM482, Pleurotus ostreatus AM600, Mucor hiemalis AM450, Yarrowia lipolytica AM71, Rhodotorula marina AM77.

The microorganisms were cultivated on Sabouraud agar slants containing aminobac $5 \mathrm{~g}$, peptone $\mathrm{K} 5 \mathrm{~g}$, glucose $40 \mathrm{~g}$ and agar $15 \mathrm{~g}$ dissolved in distilled water $(1 \mathrm{~L})$ at a temperature of $28^{\circ} \mathrm{C}$. The slants were stored in refrigerator at $4{ }^{\circ} \mathrm{C}$ and subcultured periodically.

\subsection{Screening Procedure}

Biotransformations were performed in two Erlenmeyer flasks of $300 \mathrm{~mL}$ volume with a medium consisting of $3 \mathrm{~g}$ glucose and $1 \mathrm{~g}$ peptone dissolved in distilled water $(100 \mathrm{~mL})$ at $\mathrm{pH}$ 6.8. The shaken cultures $(150 \mathrm{rpm})$ of microorganisms were cultivated at a temperature of $24^{\circ} \mathrm{C}$. After $72 \mathrm{~h}$ of shaking 
cultures were in stationary phase, $10 \mathrm{mg}$ of the substrate dissolved in $1 \mathrm{~mL}$ of acetone was added to each flask. For the next seven days, the shaken cultures with substrate were incubated. After 3, 5 and 7 days, the aliquots were taken, extracted with dichloromethane $(2 \times 15 \mathrm{~mL})$ and analyzed.

\subsection{Preparative Biotransformation}

To 10 Erlenmeyer flasks $(300 \mathrm{~mL})$ containing 3-day cultures was added substrate $(100 \mathrm{mg})$ in acetone $(10 \mathrm{~mL})$. The biotransformation was conducted in the same conditions as the screening ones. The entire content of these flasks was extracted with dichloromethane $(3 \times 40 \mathrm{~mL})$ after seven days. The combined organic fractions were dried $\left(\mathrm{MgSO}_{4}\right)$ and concentrated. Pure product was separated on silica gel (hexane: acetone 3:1). The physical and spectral data of hydroxylactone 5 (2-hydroxy-4-methyl-9-oxabicyclo [4.3.0] nonan-8-one) are presented below:

Colourless oil, ${ }^{1} \mathrm{H}$ NMR (300 MHz, $\left.\mathrm{CDCl}_{3}\right): 0.77-0.83\left(\mathrm{~m}, 1 \mathrm{H}\right.$ one of $\left.\mathrm{CH}_{2}-5\right), 0.99(\mathrm{~d}, J=6.5 \mathrm{~Hz}, 3 \mathrm{H}$, $\left.\mathrm{CH}_{3}-9\right), 1.17-1.27\left(\mathrm{~m}, 1 \mathrm{H}\right.$ one of $\left.\mathrm{CH}_{2}-3\right), 1.43-1.50(\mathrm{~m}, 1 \mathrm{H}, \mathrm{H}-4), 1.64-1.72\left(\mathrm{~m}, 1 \mathrm{H}\right.$, one of $\left.\mathrm{CH}_{2}-5\right)$, 1.82-1.89 (m, 1H, one of $\left.\mathrm{CH}_{2}-3\right), 2.27\left(\mathrm{~d}, J=16.7 \mathrm{~Hz}, 1 \mathrm{H}\right.$, one of $\left.\mathrm{CH}_{2}-7\right), 2.44-2.55(\mathrm{~m}, 1 \mathrm{H}, \mathrm{H}-6), 2.73$ $\left(\mathrm{dd}, J=16.7\right.$ and $6.4 \mathrm{~Hz}, 1 \mathrm{H}$, one of $\left.\mathrm{CH}_{2}-7\right), 3.75(\mathrm{ddd}, J=12.1,4.4,3.8 \mathrm{~Hz}, 1 \mathrm{H}, \mathrm{H}-2), 4.58(\mathrm{t}, J=3.8 \mathrm{~Hz}$, 1H, H-1), ${ }^{13} \mathrm{C} \mathrm{NMR}\left(151 \mathrm{MHz}, \mathrm{CDCl}_{3}\right): 21.7$ (C-9), 29.1 (C-4), 35.4 (C-5), 35.4 (C-6), 37.1 (C-3), 38.4 (C-7), 70.0 (C-2), 81.7 (C-1), 176.3 (C-8), IR (film, $\mathrm{cm}^{-1}$ ): 3378, 2927, 1765, 1170, 952, calcd for $\mathrm{C}_{9} \mathrm{H}_{14} \mathrm{O}_{3} \mathrm{Na}$, $m / z$ 193.0841 $(\mathrm{M}+\mathrm{H})^{+}$, found 193.0851. (SI, Figures S21-S25)

\subsection{Bioassays}

The biological tests were made by using some bacteria strains: Escherichia coli ATCC 10536, Staphylococcus aureus DSM 799, Pseudomonas fluorescens, yeast strains: Candida albicans CBS 767 and filamentous fungi strains: Aspergillus niger KKBMZ X1, Fusarium linii KKBMZ 3A. The above strains came from the collection of the Faculty of Biotechnology and Food Microbiology, Wroclaw University of Environmental and Life Sciences. Bacterial cultures were incubated for $48 \mathrm{~h}$ in a broth $(15 \mathrm{~g}$ of dry bouillon (Biocorp) and $10 \mathrm{~g}$ of glucose dissolved in $1 \mathrm{~L}$ of distilled water). Yeast and fungi were cultured in the YPG medium (10 $\mathrm{g}$ yeast extract, $10 \mathrm{~g}$ bacteriological peptone, and $10 \mathrm{~g}$ of glucose dissolved in $1 \mathrm{~L}$ of distilled water) for 48 and $96 \mathrm{~h}$, respectively, in a microbiological apparatus Bioscreen C (Automated Growth Curve Analysis System Lab Systems, Finland) to test the effects of the tested lactones on the growth of microorganisms. The working volume in the wells of the Bioscreen was $300 \mathrm{~mL}$ containing $280 \mathrm{~mL}$ of culture medium and $10 \mu \mathrm{L}$ of cells or spores (final cell density was $1 \times 10^{6} \mathrm{~mL}^{-1} \cdot \mathrm{mL}^{-1}$ ). Lactones were dissolved in dimethyl sulfoxide $(10 \mathrm{~mL})$ and used at a final concentration of $0.1 \%(w / v)$. The temperature was maintained at $30^{\circ} \mathrm{C}$ for bacteria and yeasts and $25^{\circ} \mathrm{C}$ for the filamentous fungi. The optical density of the cell suspension was measured at $550 \mathrm{~nm}$ automatically at regular intervals of $30 \mathrm{~min}$ for $2-4$ days. Cell cultures were placed on a continuous shaker. Each culture was carried out in 3 replications. Data were analysed using Excel spreadsheet (97). The mean values were used for the preparation of the growth curves for each test strain, representing a function of time of incubation and the absorbance of the medium. Curves of microbial growth were compared with the control culture medium containing dimethyl sulfoxide.

\subsection{Aphid Settling Bioassay}

The experiments were carried out using peach-potato aphid Myzus persicae (Sulz.) (1-7- day old apterous females) and Brassica pekinensis (Lour.) Rupr. (3-week old plants). Aphids and plants were reared in the laboratory under controlled conditions of $20^{\circ} \mathrm{C}, 65 \%$ r.h., and long day photoperiod (L16:8D) in the growing chamber Sanyo MLR-352H. Due to the cryptic mode of aphid feeding (they feed on plant sap and need to penetrate plant tissues with sucking-piercing mouthparts in order to reach phloem elements that are the food source), it is not possible to monitor plant acceptance directly. Neither it is possible to directly monitor the effect of exogenously applied compounds. Therefore, according to the known facts on aphid feeding behaviour [25], aphid settling bioassay is the 
commonly applied method to determine the level of plant acceptance by these insects. The studied compounds were applied as $0.1 \%$ solutions in $70 \%$ ethanol by immersing plant leaves for $30 \mathrm{~s}$ in a given solution. Leaves immersed in pure 70\% ethanol were used as controls. Treated leaves (both, control and lactone-treated ones) were offered to aphids after $1 \mathrm{~h}$ that followed the immersion. The time was necessary to let the solvent evaporate. During the experiment, aphids had a choice between treated and control leaves. The experiment was replicated 8 times for each substance and 20 aphids were used in each replicate. The number of aphids that settled, which was determined by the position of their antennae [26], was counted on each leaf 1,2, and $24 \mathrm{~h}$ after the onset of the experiment. The numbers of aphids on control and treated leaves were compared using Student's $t$-test at $p=0.05$ to reveal significant differences in preference for control or treated leaves. Based on the number of aphids settled on the control leaf $(C)$ and the number of aphids settled on the treated leaf $(T)$, the relative index of deterrence (ID) was calculated, according to the formula:

$$
I D=\frac{C-T}{C+T}
$$

The values of $I D$ ranged between 1 (ideal deterrent) and -1 (ideal attractant).

\section{Results and Discussion}

5-Methylcyclohexane-1,3-dione during the five-step synthesis was converted into the known $\gamma, \delta$-unsaturated acid [24]. This acid was then converted into chloro- $\mathbf{2}$, bromo- $\mathbf{3}$ and iodolactone 4 according to the procedure described earlier [23]. Two of these compounds, chloro- $\mathbf{2}$ and bromolactone 3 , were the new ones, only iodolactone 4 was obtained earlier [26] (Scheme 1).

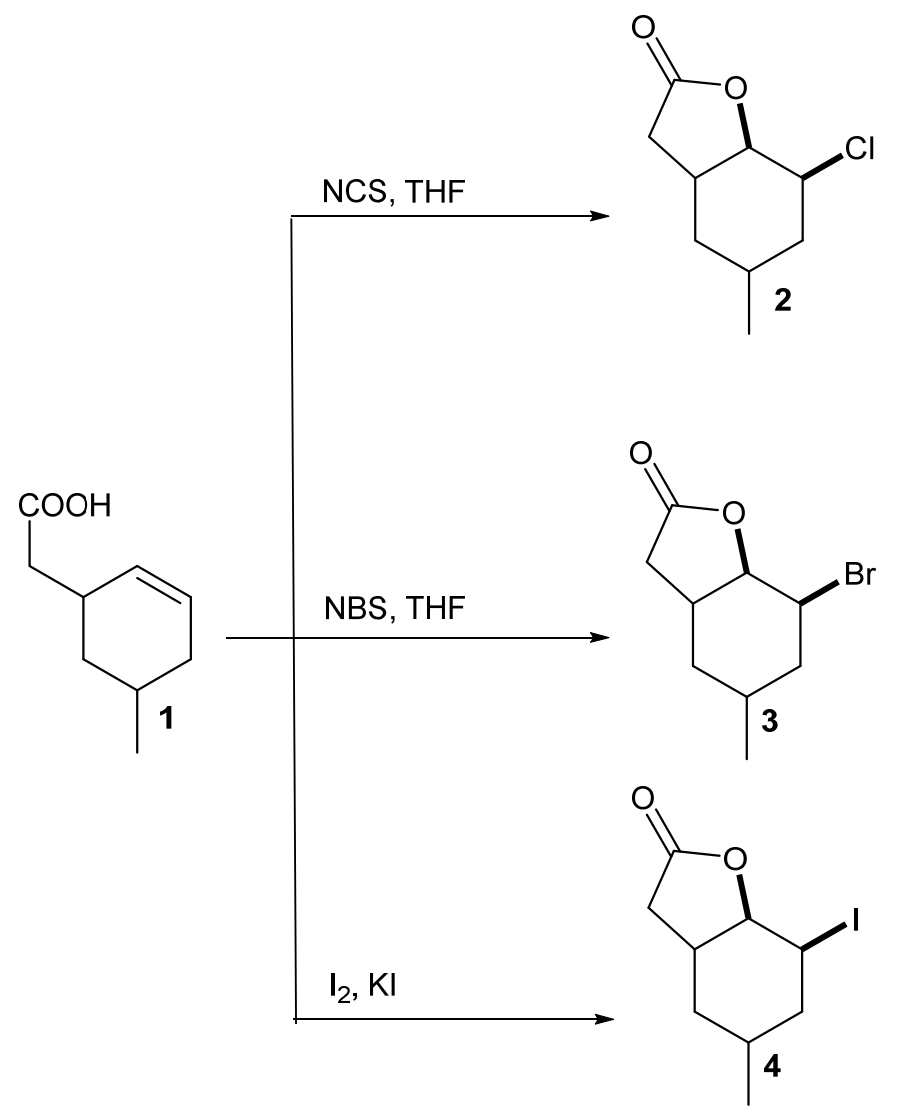

Scheme 1. Synthesis of halolactones 2-4. 
Our earlier experience $[23,27-31]$ indicated that the most common reaction for halolactones during biotransfomation was the conversion into hydroxylactones. The mechanism of such reaction was similar to $\mathrm{S}_{\mathrm{N}} 2$ substitution and $\mathrm{OH}$ group was usually introduced in an equatorial position. This kind of transformation most often is catalysed by haloalcane dehalogenases during biotransformation. The research made by Gładkowski et al. [32] conducted on iodolactone 4 proved that this compound was transformed into hydroxylactone. During this biotransformation, only one strain-Absidia cylindrospora - was tested. This strain was able to transform iodolactone into hydroxylactone with high yield but without any enantiomeric excess. Our research assumed a comparison of 22 fungal strains of their ability to biotransform three halolactones. The iodolactone in these studies was the reference compound. During the experiments, the effect of the type of halogen on the reaction was compared (Scheme 2).

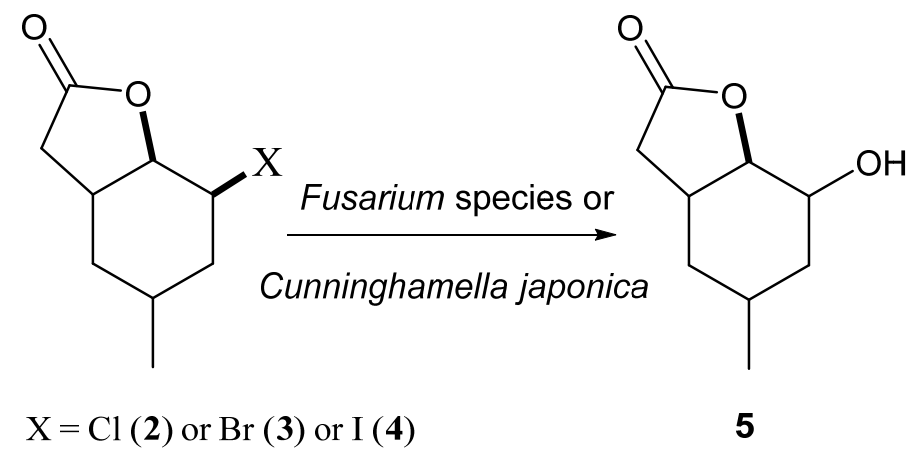

Scheme 2. The expected course of the biotransformation of halolactones $2-4$.

The progress of all screening transformations was monitored using standard techniques (TLC and GC). The chosen results of these tests are presented in Table 1. The others strains were not able to convert lactones $\mathbf{2}-\mathbf{4}$ into any product.

Table 1. The positive results of screening biotransformation of halolactones 2,3 and 4 after 7 days of incubation (in \% according to GC).

\begin{tabular}{cccccccc}
\hline \multirow{2}{*}{ Entry } & \multirow{2}{*}{ Microorganism } & \multicolumn{7}{c}{ Screening Biotransformation (\%) } \\
\cline { 3 - 7 } & & $\mathbf{( 2 )}$ & $\mathbf{( 5 )}$ & $\mathbf{( 3 )}$ & $\mathbf{( 5 )}$ & $\mathbf{( 4 )}$ & $\mathbf{( 5 )}$ \\
\hline 1 & F. culmorum AM10 & 67.4 & 42.6 & 21.3 & $\mathbf{7 2 . 7}$ & 56.0 & 44.0 \\
2 & F. avenaceum AM11 & 100 & - & 77.7 & 22.3 & 100 & - \\
3 & F. tricinctum AM16 & 100 & - & 92.4 & 7.6 & 93.7 & 6.3 \\
4 & F. semitectum AM20 & 100 & - & 87.3 & 12.7 & 95.3 & 4.7 \\
5 & F. oxysporum AM21 & 100 & - & 89.7 & 10.3 & 100 & - \\
6 & S. racemosum AM105 & 100 & - & 72.7 & 27.3 & 100 & - \\
7 & F. solani AM203 & 87.7 & 12.3 & 67.1 & 32.9 & 61.7 & 38.3 \\
8 & C. japonica AM472 & 32.5 & $\mathbf{6 7 . 5}$ & 45.2 & 54.8 & 34.0 & $\mathbf{6 6 . 0}$ \\
\hline
\end{tabular}

The results of the conducted experiments were very surprising. It turned out that of the 22 tested microorganisms, only some were capable of converting the chosen substrates. The best biocatalyst was C. japonica AM472 strain (entry 8). This strain was able to transform all three halolactones with a high degree of conversion (between $54.8 \%$ and $67.5 \%$ ). Of the strains of genus Fusarium, only F. culmorum AM10 (entry 1) converted bromolactone 3 with a satisfying yield (almost 73\%). Usually strains of genus Fusarium were very good biocatalysts for halolactones and transform halolactones independently of halogen. Contrary to the results described in our earlier papers $[26,28,29,32]$ from five strains of genus Fusarium, only one was able to convert the chosen substrates into product with a good yield. Independent of the structure of the compound, the best substrate for biotransformation was 
bromolactone 3, which was converted by eight strains. A slightly worse situation was observed for iodolactone 4 , converted by five strains. The chlorolactone 2 was the least susceptible to biotransformation (three strains only). Only two strains, C. japonica AM472 and F. culmorum AM10, were able to transform all of the compounds in good yield. Both strains are known for the high activity of enzymes associated with cytochrome P450 [33], which explains their high tolerance in the dehalogenation reaction to various substrates. Taking into account the results obtained during the screening biotransformation, we decided to perform the preparative scale biotransformation on only two selected strains: The results of this step are presented in Table 2.

Table 2. Results of the preparative scale biotransformations of halolactones $2-4$ after 7 days of incubation (in \% according to GC).

\begin{tabular}{ccccccc}
\hline Microorganism & Substrate (2) & Product (5) & Substrate (3) & Product (5) & Substrate (4) & Product (5) \\
\hline C. japonica AM472 & 40.0 & 60.0 & 44.8 & 55.2 & 42.5 & 57.5 \\
F. culmorum AM10 & - & - & 21.1 & 78.8 & - & - \\
\hline
\end{tabular}

Both strains: C. japonica and F. culmorum, converted lactones 2-4 into the same product, which was hydroxylactone 5 . The best degree of conversion was observed for bromolactone 3 when the F. culmorum stain was used as a biocatalyst (78.8\% of lactone 5). In the case of $C$. japonica, the degree of conversion was similar for all three substrates, the amount of product ranging from $55 \%$ to $60 \%$. In the next step, an isolated yield, the enantiospecificity and optical purity of hydroxylactone 5 obtained during all preparative biotransformation were determined. The results of this step are shown in Table 3 .

Table 3. Results of preparative biotransformation of lactones 2-4.

\begin{tabular}{cccc}
\hline Substrate & Strain & Isolated Yield mg/\% & ee (\%) \\
\hline chlorolactone 2 & C. japonica AM472 & $10 / 11.1$ & 4.0 \\
bromolactone 3 & F. culmorum AM10 & $27 / 37.4$ & 14.9 \\
bromolactone 3 & C. japonica AM472 & $16 / 21.9$ & 17.7 \\
iodolactone 4 & C. japonica AM472 & $16 / 25.7$ & 6.4 \\
\hline
\end{tabular}

As we can see in Table 3, the enantiomeric excesses of all hydroxylactones were low. Such a situation was probably caused by the structure of the substrates, in which only one steric hindrance was the methyl group at C-5 carbon. The hydroxylactone 5 with the highest enantiomeric excess $(17.7 \%)$ was obtained from bromolactone 3 . In all cases, hydroxylactone was created with a slight excess of (+)-enantiomer.

During the conducted biotransformation, the strong impact of the structure of lactones 2-4 on the possibility of their conversion into hydroxylactone could be observed. Because of that, the structures of these compounds were established on the basis of their spectral data $\left({ }^{1} \mathrm{H} \mathrm{NMR},{ }^{13} \mathrm{C}\right.$ NMR, COSY, HMQC and IR) and confirmed by HRMS analysis. The absorption bands lying at 1787 (for 2), 1799 (for 3) and 1792 (for 4) $\mathrm{cm}^{-1}$ on the IR spectra confirmed the presence of the $\gamma$-lactone ring in these molecules. Analysis of the ${ }^{1} \mathrm{H}$ NMR spectra proved that the cyclohexane ring in these three lactones took a chair conformation. Wide multiplet coming from proton $\mathrm{H}-4$ suggested the equatorial orientation of the $\mathrm{CH}_{3}-9$ group. The shapes of signals coming from proton $\mathrm{H}-6$ (wide multiplet) and proton $\mathrm{H}-1$ (small coupling constant) indicated their axial (H-6) and equatorial (H-1) orientation. It means that the $\mathrm{C}-\mathrm{O}$ bond of lactone ring is located in an axial position. Signal coming from proton $\mathrm{H}-2$ looked like a wide singlet suggesting its equatorial orientation and thereby indicating that the halogen atom assumed an axial position.

Analysis of ${ }^{1} \mathrm{H}$ NMR spectra of halolactones 2-4 and hydroxylactone 5 proved that the cyclohexane ring in these four lactones took a chair conformation. The only difference in the structure of the substrates and product was the location of the halogen atom and hydroxy group. In the molecules of 
lactones 2-4, the halogen atom assumed an axial position. In the molecule of the hydroxylactone 5, the hydroxy group occupied an equatorial position (Figure 1).
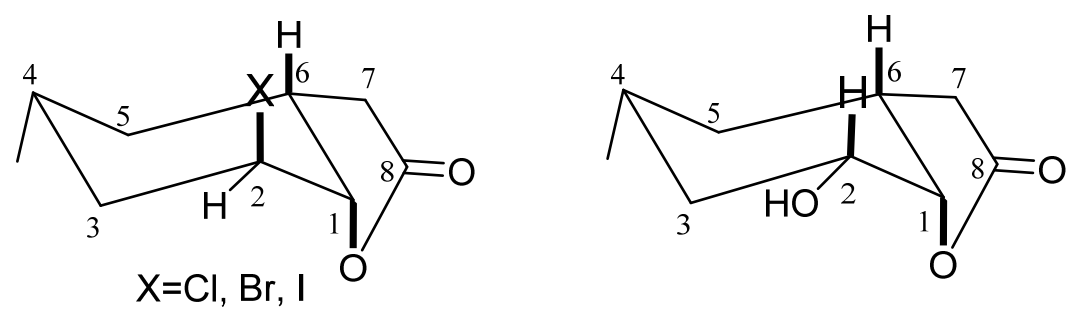

Figure 1. Structure of lactones 2-5.

The above analysis shows that the hydroxylactone 5 obtained during the biotransformation presented here is analogous to the hydroxylactone obtained earlier from iodolactone 4 by Gładkowski etal. [27]. It is important to notice that hydroxylactone $\mathbf{5}$ obtained during biotransformation was structurally different to its analog obtained synthetically [31]. It was ascertained based on the comparison between ${ }^{1} \mathrm{H}$ NMR spectra of both compounds. The main difference was the shape and position of signals coming from the protons $\mathrm{H}-1$ and H-2. In the obtained microbiological hydroxylactone 5 signal coming from proton $\mathrm{H}-2$ lying at $3.75 \mathrm{ppm}$ there was a doublet of doublet of doublet, while the signal of proton $\mathrm{H}-1$ was a triplet lying at $4.58 \mathrm{ppm}$. In the above cited synthetic hydroxylactone only one narrow multiplet coming from protons $\mathrm{H}-2$ and $\mathrm{H}-1$ lying at $4.27 \mathrm{ppm}$ was observed. These differences were the consequence of the different position of a hydroxy group. In hydroxylactone 5 obtained by biotransformation, a hydroxy group was situated in an equatorial position, while in hydroxylactone obtained by chemical synthesis, it was situated in an axial one.

Unfortunately, we were not able to obtain hydroxylactone 5 with such high yield as described in the abovementioned article. However, use of bromolactone 3 for biotransformation gave hydroxylactone 5 with a small (17.7\%) enantiomeric excess.

As it is known, the different bicyclic lactones were often endowed with interesting biological properties such as antifeedant activity against storage pests, Colorado potato beetle, and aphids $[17,34,35]$ or the inhibition of the growth of some microorganisms $[27,28,31]$. Knowing that, the lactones presented here were tested in this respect. Halolactones 2-4 and hydroxylactone $\mathbf{5}$ were examined for their ability to inhibit the growth of some bacteria, yeast and fungal strains. The highest activity against the tested microorganisms showed bromolactone 3 and iodolactone 4 . The smallest one was the product of biotransformation-hydroxylactone 5 . The results of these tests are presented in Figures 2-7.

Of the tested bacteria strains, the highest sensitivity was demonstrated by the $S$. aureus strain. Its growth was completely inhibited by lactones $\mathbf{2}-\mathbf{4}$. Also, lactone $\mathbf{5}$ showed a negative impact on the growth of this strain causing a significant extension of the adaptive phase (20-36 h) and a small increase in biomass expressed as $\triangle \mathrm{OD}$ in the range $0.36-0.62$.

Also, filamentous fungi proved to be susceptible to the microbial activity of some test compounds. Lactones 3 and 4 completely inhibited the growth of the F. linii strain, and significantly limited the expansion of the $A$. niger strain. Fungi strains proved to be insensitive to the activity of lactone 5 . This compound even stimulated the growth of the fungus $F$. linii, resulting in a greater increase in biomass of about 0.58 , as compared to the control culture. 


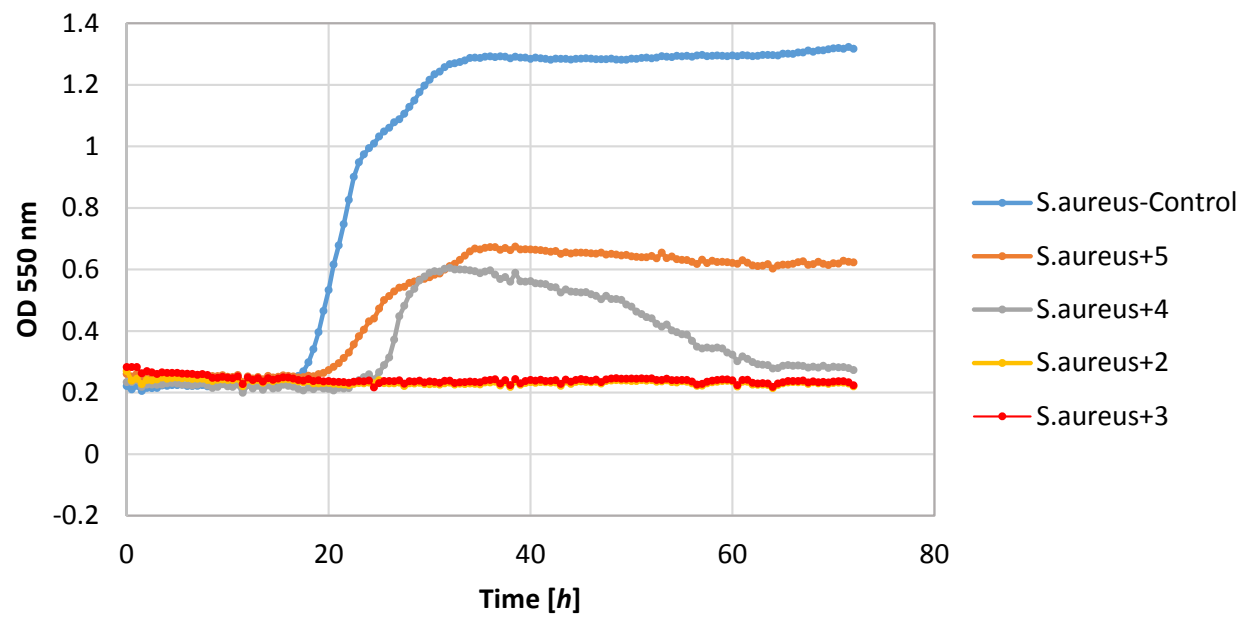

Figure 2. The assessment of the effects of the lactones $\mathbf{2}-\mathbf{5}$ on the growth of S. aureus. (OD-Optical Density was measured for $\lambda 550 \mathrm{~nm}$ ).

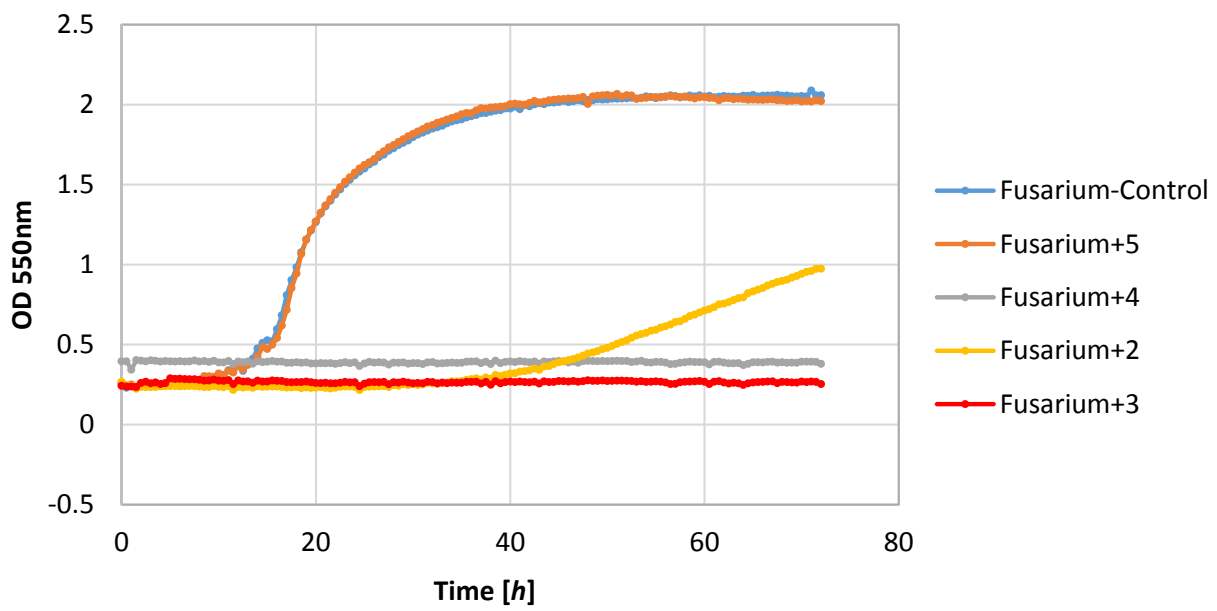

Figure 3. The assessment of the effects of the lactones $\mathbf{2}-\mathbf{5}$ on the growth of F. linii. (OD-Optical Density was measured for $\lambda 550 \mathrm{~nm}$ ).

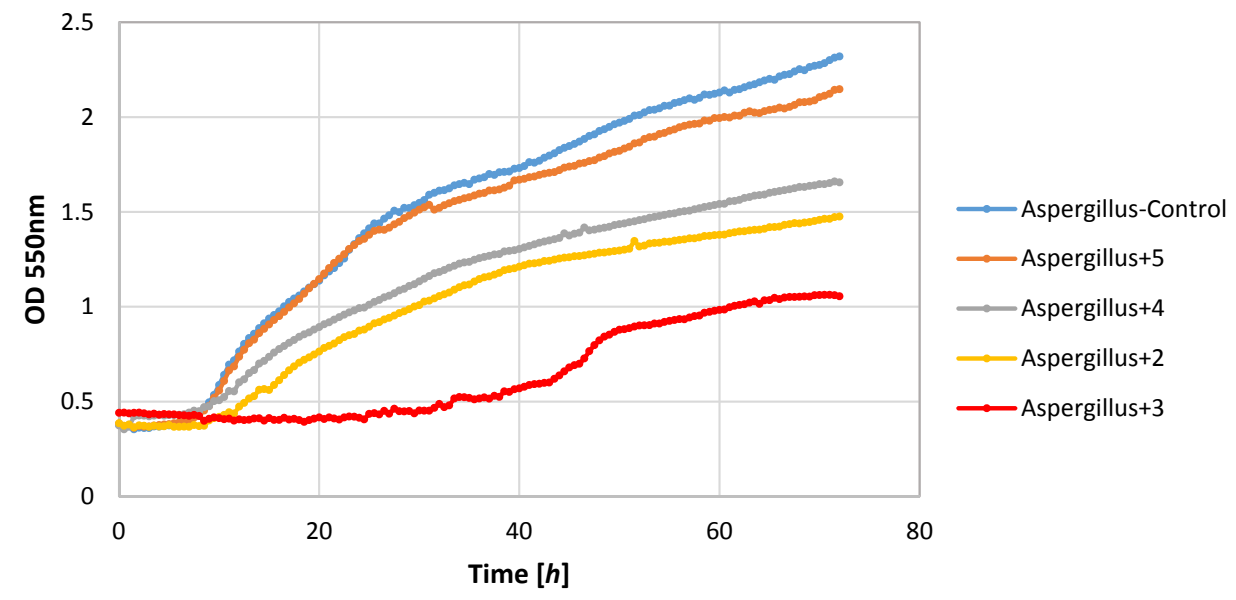

Figure 4. The assessment of the effects of the lactones $\mathbf{2}-\mathbf{5}$ on the growth of A.niger. (OD-Optical Density was measured for $\lambda 550 \mathrm{~nm}$ ). 


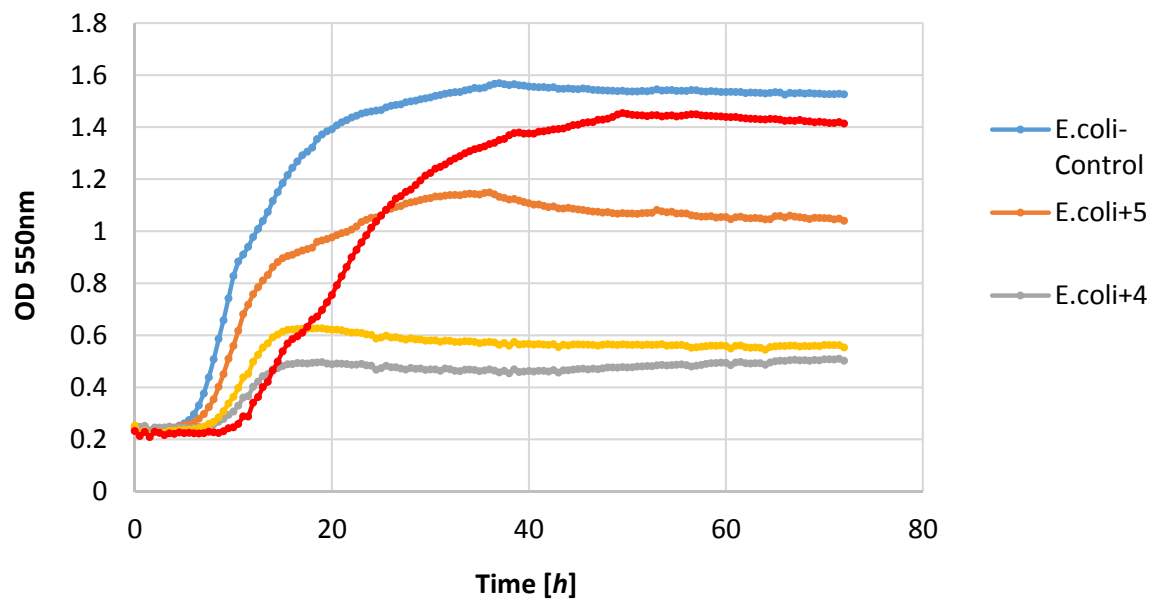

Figure 5. The assessment of the effects of the lactones 2-5 on the growth of E. coli. (OD-Optical Density was measured for $\lambda 550 \mathrm{~nm}$ ).

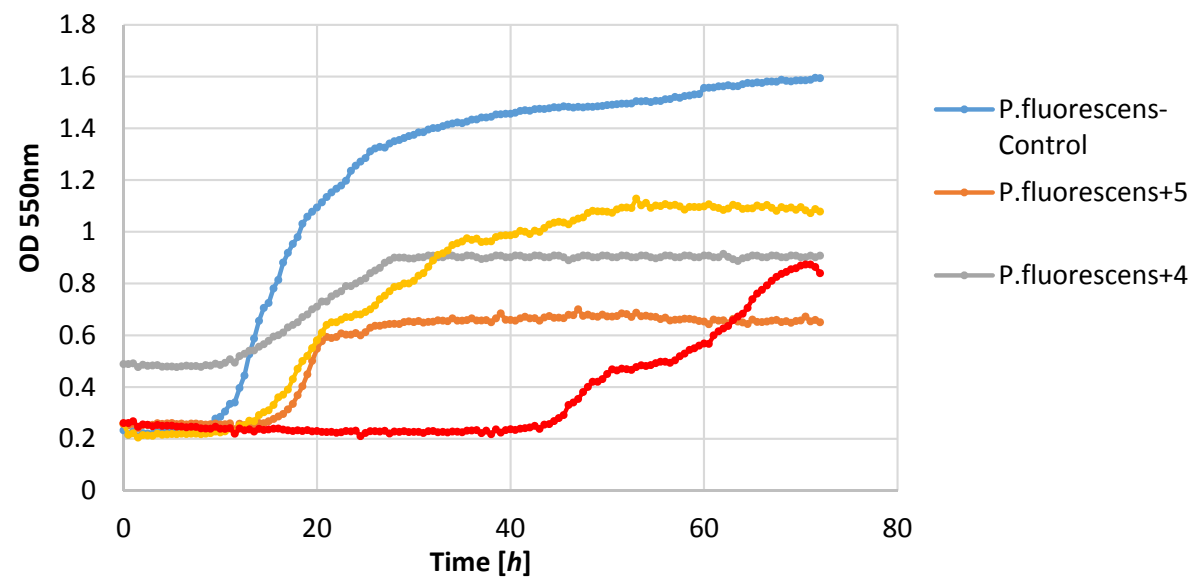

Figure 6. The assessment of the effects of the lactones $\mathbf{2}-\mathbf{5}$ on the growth of P. fluorescens (OD-Optical Density was measured for $\lambda 550 \mathrm{~nm}$ ).

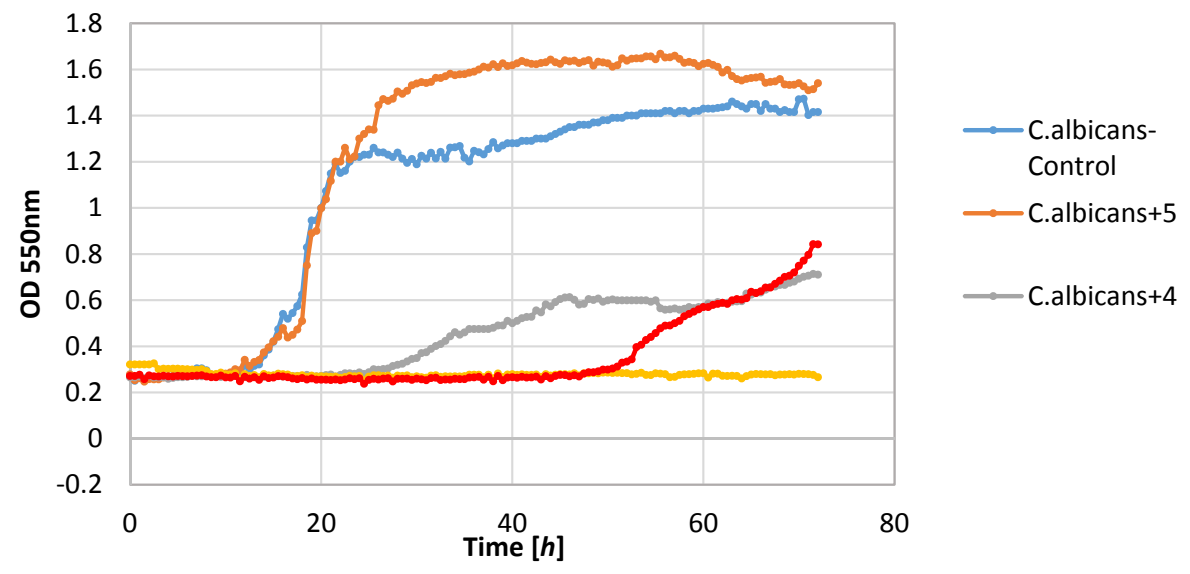

Figure 7. The assessment of the effects of the lactones $\mathbf{2 - 5}$ on the growth of $C$. albicans (OD-Optical Density was measured for $\lambda 550 \mathrm{~nm}$ ). 
Most of the lactones tested caused the inhibition of growth of the E. coli strain. The highest growth inhibition, $\Delta \mathrm{OD}=0.25-0.57$, was shown in compounds 2 and 4 . Lactone 5 limited the increase in the biomass.

P. fluorescens strain growth was limited by lactones $3-5$. The increase in the optical density of this strain was in the range 0.39-0.58, whereas in the control culture it was 1.36. It is worth noting that in the culture of the $P$. fluorescens strain that was conducted in the presence of compound 4, the diauxic growth was observed. A similar effect was observed earlier for bacteria strain $E$. coli and yeast strain C. albicans [21]. This phenomenon was also reported by other authors [36-38].

The yeast strain C. albicans was found to be relatively sensitive to lactones $\mathbf{2 - 4}$, wherein only compound 2 completely inhibited growth. The other compounds limited the increase in the biomass. It should be noted that compound 5 stimulated the growth of this yeast resulting in the increase in biomass $\triangle \mathrm{OD}$ equal to 1.26 , whereas the control culture yeasts' value was 1.14.

In the next step, halolactones $\mathbf{2}-\mathbf{4}$ and hydroxylactone $\mathbf{5}$ were examined for their deterrent activity against the peach potato aphid Myzus persicae (Sulz.). The results of these tests are presented in Table 4.

Table 4. Deterrent activity of lactones 2-5. Numbers for $C=$ control and $T=$ treated represent mean number $( \pm \mathrm{SE})$ of aphids that settled on the control or the treated leaf (choice-test) $1 \mathrm{~h}, 2 \mathrm{~h}$, and $24 \mathrm{~h}$ after exposure. $p$ —significance level (Student's $t$-test; StatSoft, Inc. (2014) STATISTICA)—significant differences $(p<0.05)$ between the number of aphids settled on either leaf are underlined.

\begin{tabular}{cccccccccc}
\hline \multirow{2}{*}{ Lactone } & \multicolumn{3}{c}{$\mathbf{1} \mathbf{h}$} & \multicolumn{3}{c}{$\mathbf{2} \mathbf{h}$} & \multicolumn{3}{c}{$\mathbf{2 4} \mathbf{h}$} \\
\cline { 2 - 10 } & $\boldsymbol{C}$ & $\boldsymbol{T}$ & $\boldsymbol{p}$ & $\boldsymbol{C}$ & $\boldsymbol{T}$ & $\boldsymbol{p}$ & $\boldsymbol{C}$ & $\boldsymbol{T}$ & $\boldsymbol{p}$ \\
\hline $\mathbf{2}$ & $6.8 \pm 0.9$ & $5.3 \pm 0.8$ & 0.2100 & $7.3 \pm 1.0$ & $5.6 \pm 1.0$ & 0.2602 & $14.4 \pm 0.8$ & $5.0 \pm 0.7$ & $\underline{0.0000}$ \\
$\mathbf{3}$ & $9.3 \pm 0.8$ & $7.0 \pm 1.3$ & 0.1611 & $9.8 \pm 1.0$ & $6.5 \pm 1.2$ & 0.0507 & $13.0 \pm 2.1$ & $5.4 \pm 2.1$ & $\underline{0.0219}$ \\
$\mathbf{4}$ & $6.1 \pm 1.1$ & $6.4 \pm 1.2$ & 0.8811 & $7.1 \pm 0.9$ & $6.4 \pm 1.3$ & 0.6546 & $7.6 \pm 1.5$ & $5.6 \pm 1.9$ & 0.4304 \\
$\mathbf{5}$ & $5.6 \pm 1.7$ & $5.9 \pm 0.9$ & 0.8978 & $6.5 \pm 1.7$ & $5.4 \pm 0.7$ & 0.5571 & $6.1 \pm 2.0$ & $10.6 \pm 2.3$ & 0.1599 \\
\hline
\end{tabular}

Iodolactone $\mathbf{4}$ and hydroxylactone $\mathbf{5}$ did not affect aphid behavior during settling in a significant way. Nevertheless, lactone $\mathbf{4}$ showed a tendency to inhibit aphid settling, while $\mathbf{5}$ appeared to be a weak attractant. Chlorolactone 2 and bromolactone 3 caused a significant avoidance of the treated leaves by the aphids later than two hours after exposure but the indices of deterrence (ID) calculated on the 24th hour reached the relatively high values of 0.5 and 0.4, respectively (Table 4, Figure 8). Similar effects were obtained when studying the effect of piperitone-derived halolactones on M. persicae settling behavior: the incorporation of chlorine, bromine and iodine atoms in the lactone molecule caused a significant increase in deterrent activity [39]. In the cited study, the strongest effects were attributed to chlorine and bromine atoms while the effect of iodine atom on the activity was less pronounced [39].

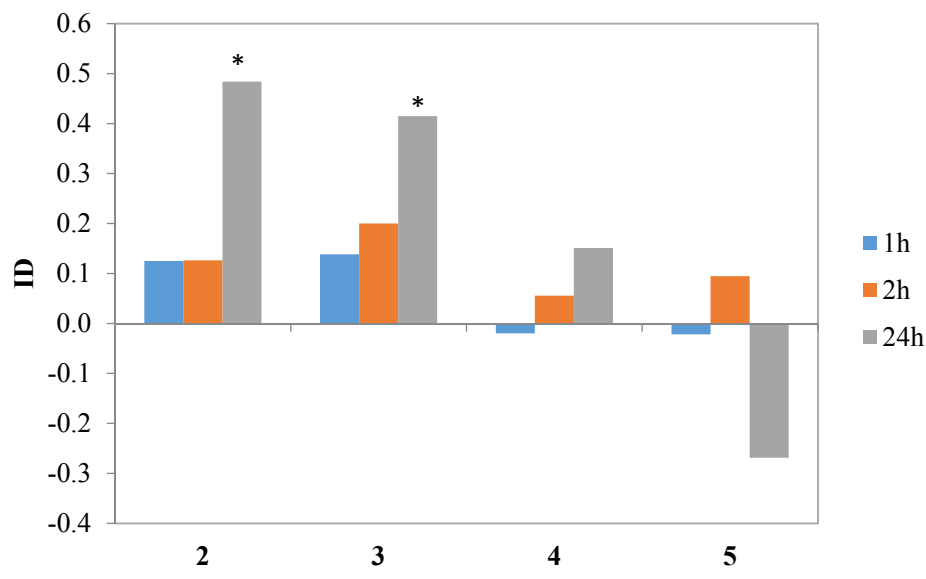

Figure 8. Effect of lactones 2-5 on settling preferences of Myzus persicae in the choice test. ID—index of deterrence, ${ }^{*} p<0.05$ (Student $t$-test). 


\section{Conclusions}

The 22 fungal strains were tested for their ability to transform three halolactones $\mathbf{2 - 4}$. Only two of these strains (C. japonica AM472 and F. culmorum AM10) were able to conduct the reaction of hydrolytic dehalogenation of the chosen substrates, giving hydroxylactone as a product. The best result was obtained when bromolactone 3 was transformed by the F. culmorum AM10 strain. Enantiomeric excesses were low, but in all cases the (+)-enantiomer was produced in excess. Chloro- 2, bromo- 3, iodo- $\mathbf{4}$ and hydroxylactone 5 were then subjected to biological tests. The growth inhibition tests were conducted on the chosen strains of bacteria, yeast and filamentous fungi. Complete inhibition of growth of $S$. aureus strain was caused by lactones 2,3 and 4 . Lactone 2 caused complete inhibition of growth of $C$. albicans strain. The same effect was observed for lactones 3 and 4 when F. linii strain was tested. Lactones 2, 3, 4 limited the increase in the biomass of E. coli, P. fluorescens and A. niger strains. Lactone 5 also limited the increase in the biomass of $S$. aureus and P. fluorescens strains. Other assays were performed on the peach potato aphid. These tests showed that lactone 4 was inactive against M. persicae. Lactones 2 and 3 showed deterrent activity. Indices of deterrence after $24 \mathrm{~h}$ reached the relatively high values of 0.5 and 0.4 for compounds 2 and 3, respectively. Lactone 5 showed a weak attractant activity after $24 \mathrm{~h}$.

Supplementary Materials: The following are available online at www.mdpi.com/2076-3417/7/1/12/s1.

Acknowledgments: Publication supported by Wroclaw Centre of Biotechnology, programme The Leading National Research Centre (KNOW) for years 2014-2018.

Author Contributions: Katarzyna Wińska conceived, designed the experiments and analyzed the data, Katarzyna Wińska and Wanda Mączka performed the experiments, Katarzyna Wińska and Małgorzata Grabarczyk wrote the paper, Barbara Żarowska, Katarzyna Dancewicz and Beata Gabryś performed the biological analysis, Gabriela Maciejewska performed the high resolution mass spectrometry analysis, Mirosław Anioł contributed for the discussion of results. All authors read and approved the final manuscript.

Conflicts of Interest: The authors declare no conflict of interest.

\section{References}

1. Okutsu, N.; Morohoshi, T.; Xie, X.; Kato, N.; Ikeda, T. Characterization of N-Acylhomoserine lactones produced by bacteria isolated from industrial cooling water systems. Sensors 2016, 16. [CrossRef] [PubMed]

2. Schulz, S.; Hötling, S. The use of the lactone motif in chemical communication. Nat. Prod. Rep. 2015, 32, 1042-1066. [CrossRef] [PubMed]

3. Chadwick, M.; Trewin, H.; Gawthrop, F.; Wagstaff, C. Sesquiterpenoids lactones: Benefits to plants and people. Int. J. Mol. Sci. 2013, 14, 12780-12805. [CrossRef] [PubMed]

4. Zhang, L.; An, R.; Wang, J.; Sun, N.; Zhang, S.; Hu, J.; Kuai, J. Exploring novel bioactive compounds from marine microbes. Curr. Opin. Microbiol. 2005, 8, 276-281. [CrossRef] [PubMed]

5. Djeddi, S.; Karioti, A.; Sokovic, M.; Koukoulitsa, C.; Skaltsa, H. A novel sesquiterpene lactone from Centaurea pullata: Structure elucidation, antimicrobial activity, and prediction of pharmacokinetic properties. Bioorg. Med. Chem. 2008, 16, 3725-3731. [CrossRef] [PubMed]

6. Pérez Gutiérrez, R.M. An antibacterial sesquiterpene lactone from fresh-water alga Vaucheria sessilis. Bol. Latinoam. Caribe Med. Aromat. 2009, 8, 289-294.

7. Pujar, P.P.; Sawaikar, D.D.; Rojatkar, S.R.; Nagasampagi, B.A. A new germacranolide from Artemisia pallens. Fitoterapia 2000, 71, 590-592. [CrossRef]

8. Rodrigues, A.M.S.; Theodoro, P.N.E.T.; Eparvier, V.; Basset, C.; Silva, M.R.R.; Beauchene, J.; Espindola, L.S.; Stien, D. Search for antifungal compounds from the wood of durable tropical trees. J. Nat. Prod. 2010, 73, 1706-1707. [CrossRef] [PubMed]

9. Fortuna, A.M.; Juarez, Z.N.; Bach, H.; Nematallah, A.; Av-Gay, Y.; Sanchez-Arreola, E.; Catalan, C.A.N.; Turbay, S.; Hernandez, L.R. Antimicrobial activities of sesquiterpene lactones and inositol derivatives from Hymenoxys robusta. Phytochemistry 2011, 72, 2413-2418. [CrossRef] [PubMed]

10. Liu, Q.; Ahn, J.H.; Kim, S.B.; Lee, C.; Hwang, B.Y.; Lee, M.K. Sesquiterpene lactones from the roots of Lindera strychnifolia. Phytochemistry 2013, 87, 112-118. [CrossRef] [PubMed] 
11. Nagarapu, L.; Kumar, U.N.; Upendra, P.; Bantu, R. Simple, convenient method for the synthesis of substituted furan-2(5H)-one derivatives using Tin(II) chloride. Synth. Commun. 2012, 42, 2139-2148. [CrossRef]

12. Von Ettlinger, L.; Gaumann, E.; Hutter, R.; Keller-Schierlain, W.; Kradolfer, F.; Neipp, L.; Prelog, V.; Zahler, H. Stoffwechselprodukte von Actinomyceten. 12. Mitteilung. Über die Isolierung und Charakterisierung von Acetomycin. Helv. Chim. Acta 1958, 41, 216-219. (In German) [CrossRef]

13. Von Bosshard, E.; Goackner, N.A.; Keller-Schierlein, W. Stoffwechselprodukte von Actinomyceten. 20. Mitteilung. Synthese des $\alpha, \beta$-Dimethyllävulinaldehyds, eines Abbau-Produktes von Acetomycin. Helv Chim Acta. 1959, 42, 2746-2751. (In German) [CrossRef]

14. Echavarren, A.M.; de Mendoza, J.; Prados, P.; Zapata, A. Stereoselective synthesis of ( \pm )-4-epi-acetomycin by the ester enolate Carroll rearrangement. Tetrahedron Lett. 1991, 32, 6421-6424. [CrossRef]

15. Luna-Herrera, J.; Costa, M.C.; González, H.G.; Rodrigues, A.I.; Castilho, P.C. Synergistic antimycobacterial activities of sesquiterpene lactones from Laurus spp. J. Antimicrob. Chemother. 2007, 59, 548-552. [CrossRef] [PubMed]

16. Van Beek, T.A.; de Groot, E. Terpenoid antifeedants, part I. An overview of terpenoid antifeedants of natural origin. Rec. Trav. Chim. Pays-Bas 1986, 105, 513-527. [CrossRef]

17. Wawrzeńczyk, C.; Grabarczyk, M.; Szumny, A.; Gabryś, B.; Dancewicz, K.; Nawrot, J.; Prądzyńska, A.; Halarewicz-Pacan, A. Lactones 19. Synthesis and antyfeedant activity of lactones with metyl-, dimethyl- and trimethylcyclohexanane system. Chem. For. Agric. Czech Pol. Trade 2003, 4, 117-129.

18. Enk, C.D.; Hochberg, M.; Torres, A.; Lev, O.; Dor, I.; Srebrnik, M.; Dembitsky, V.M. Photoprotection by Cichorium endivia extracts: Prevention of UVB-Induced erythema, pyrimidine dimer formation and IL-6 expression. Skin Pharm. Phys. 2004, 17, 42-48. [CrossRef] [PubMed]

19. Pan, L.; Lantvit, D.D.; Riswan, S.; Kardono, L.B.S.; Chai, H.-B.; Carcache de Blanco, E.J.; Farnsworth, N.R.; Doel Soejarto, D.; Swanson, S.M.; Kinghorn, A.D. Bioactivity-guided isolation of cytotoxic sesquiterpenes of Rolandra fruticosa. Phytochemistry 2010, 71, 635-640. [CrossRef] [PubMed]

20. Chen, J.J.; Li, W.X.; Gao, K.; Jin, X.J.; Yao, X.J. Absolute structures of monoterpenoids with a ס-lactone-containing skeleton from Ligularia hodgsonii. J. Nat. Prod. 2012, 75, 1184-1188. [CrossRef] [PubMed]

21. Grabarczyk, M.; Wińska, K.; Maciejewska, G.; Dancewicz, K.; Mączka, W.; Gabryś, B.; Żarowska, B.; Anioł, M. Synthesis, biotransformation and biological activity of halolactones obtained from $\beta$-ionone. Tetrahedron 2016, 72, 637-644. [CrossRef]

22. Wińska, K.; Grabarczyk, M.; Mączka, W.; Żarowska, B.; Maciejewska, G.; Dancewicz, K.; Gabryś, B.; Szumny, A.; Anioł, M. Biotransformation of bicyclic halolactones with a methyl group in the cyclohexane ring into hydroxylactones and their biological activity. Molecules 2016, 21, 1453. [CrossRef] [PubMed]

23. Grabarczyk, M.; Białońska, A. Biotransformations of chloro-, bromo- and iodolactone with trimethylcyclohexane system using fungal strains. Biocatal. Biotransform. 2010, 28, 408-414. [CrossRef]

24. Grabarczyk, M.; Szumny, A.; Gładkowski, W.; Białońska, A.; Ciunik, Z.; Wawrzeńczyk, C. Lactones 18. Synthesis of bicyclic lactones with methyl-, di- and trimethyl substituted cyclohexane system. Pol. J. Chem. 2005, 79, 1763-1771. [CrossRef]

25. Harrewijn, P. Resistance mechanisms of plant genotypes to various aphid species. In Aphid-Plant Genotype Interactions; Campbell, R.K., Eikenbary, R.D., Eds.; Elsevier: Amsterdam, The Netherlands, 1990; pp. 117-130.

26. Hardie, J.; Holyoak, M.; Taylor, N.J.; Griffiths, D.C. The combination of electronic monitoring and video-assisted observations of plant penetration by aphids and behavioural effects of polygodial. Entomol. Exp. Appl. 1992, 62, 233-239. [CrossRef]

27. Grabarczyk, M.; Wińska, K.; Mączka, W.; Żarowska, B.; Białońska, A.; Anioł, M. Hydroxylactones with the gem-dimethylcyclohexane system-Synthesis and antimicrobial activity. Arab. J. Chem. 2015, in press. [CrossRef]

28. Grabarczyk, M. Fungal strains as catalysts for the biotransformation of halolactones by hydrolytic dehalogenation with the dimethylcyclohexane system. Molecules 2012, 17, 9741-9753. [PubMed]

29. Grabarczyk, M.; Maczka, W.; Wińska, K.; Żarowska, B.; Anioł, M. Antimicrobial activity of hydroxylactone obtained by biotransformation of bromo- and iodolactone with gem-dimethylcyclohexane ring. J. Braz. Chem. Soc. 2013, 24, 1913-1919. [CrossRef]

30. Grabarczyk, M.; Wińska, K.; Mączka, W.; Żołnierczyk, A.K.; Żarowska, B.; Anioł, M. Lactones with methylcyclohexane system obtained by chemical and microbiological methods and their antimicrobial activity. Molecules 2015, 20, 3335-3353. [CrossRef] [PubMed] 
31. Wawrzeńczyk, C.; Grabarczyk, M.; Białońska, A.; Ciunik, J. Lactones 16. Lactonization of $\gamma, \delta$-epoxy esters with p-toluenesulfonic acid monohydrate. Tetrahedron 2003, 59, 6595-6601. [CrossRef]

32. Gładkowski, W.; Mazur, M.; Białońska, A.; Wawrzeńczyk, C. Lactones 35. Metabolism of iodolactones with cyclohexane ring in Absidia cylindrospora culture. Enzym. Microb. Technol. 2011, 48, 326-333. [CrossRef] [PubMed]

33. Črešnar, B.; Petrič, Š. Cytochrome P450 enzymes in the fungal kingdom. Biochim. Biophys. Acta 2011, 1814, 29-35. [CrossRef] [PubMed]

34. Dancewicz, K.; Gabryś, B.; Halarewicz-Pacan, A.; Grabarczyk, M.; Wawrzeńczyk, C. Effect of terpenoid lactones with di- and trimethylcyclohexane system on behaviour of green peach aphid Myzus persicae. Pestycydy 2005, 4, 17-23.

35. Lochyński, S.; Frackowiak, B.; Olejniczak, T.; Ciunik, Z. Lactones. Part 15: Synthesis of chiral spirolactones with a carane system-Insect feeding deterrents. Tetrahedron Asymm. 2002, 13, 1761-1767. [CrossRef]

36. Monod, J. Recherches sur la croissance des cultures bacteriennes (Studies on the growth of bacterial cultures). Actual. Sci. Ind. 1942, 911, 1-215. (In French)

37. Narang, A.; Pilyugin, S.S. Bacterial gene regulation in diauxic and nondiauxic growth. J. Theor. Biol. 2007, 244, 326-348. [CrossRef] [PubMed]

38. Loomis, W.F., Jr.; Magasanik, B. Glucose-lactose diauxie in Escherichia coli. J. Bacteriol. 1967, 93, $1397-1401$. [PubMed]

39. Grudniewska, A.; Dancewicz, K.; Białońska, A.; Ciunik, Z.; Gabryś, B.; Wawrzeńczyk, C. Synthesis of piperitone-derived halogenated lactones and their effect on aphid probing, feeding, and settling behavior. RSC Adv. 2011, 1, 498-510. [CrossRef]

(C) 2016 by the authors; licensee MDPI, Basel, Switzerland. This article is an open access article distributed under the terms and conditions of the Creative Commons Attribution (CC-BY) license (http://creativecommons.org/licenses/by/4.0/). 